\title{
NOOSPHERIC PERSONALITY: COMPETENCIES IN DISTANCE LEARNING ENVIRONMENT
}

\author{
L.K. Geykhman', glk@pstu.ru, \\ I.V. Stavtseva², stavtsevaiv@susu.ru \\ ${ }^{1}$ Perm National Research Polytechnic University, Perm, Russian Federation, \\ ${ }^{2}$ South Ural State University, Chelyabinsk, Russian Federation
}

\begin{abstract}
Since human civilization, including the educational system, is currently experiencing a deep crisis, the issues of noogenesis are becoming especially relevant. It means that the development of society is primarily the spiritual development of each individual, who is ready for productive interaction in order to save the planet from human destruction. Nevertheless, the situation of COVID19 pandemic showed how the modern world is losing its face-to-face communication becoming more computer-mediated, data-overwhelmed and online-dependent. Consequently, the task of forming the noospheric personality becomes crucial in new conditions, and this task can be solved by pedagogy. The current paper defines noospheric personality and addresses the issues of competence development in distance learning. The objective of the research is to develop the model of due competences in distance learning noosphere. The methods used include the analysis of the theories and concepts in the references provided and modeling the pedagogical process. The results are represented in two interconnected pedagogical models: the model of distance learning participants' interaction system in the aspect of noospheric pedagogy and competence model of noospheric personality. The interaction model structurally summarises the process of distance learning communications while competence model outlines the content of noospheric personality's development, pointing out the transition from competences to personal culture and highlighting the importance of civic consciousness as the main mover that brings real change. The research demonstrates a new efficient way of dealing with modern systemic educational crisis and can be used as a guide in making distance learning programs and courses.
\end{abstract}

Keywords: noospheric personality, noospheric pedagogy, synergetic pedagogy, coevolutionary interaction, distance learning, competence formation, personal culture, civic consciousness.

\section{Introduction}

In spite of the fact that the understanding of noosphere by modern scholars is ambiguous $[5,8-10,14,16,18-20]$, we agree with those academics who believe that noosphere is a manifestation of the co-evolutionary process of material and spiritual systems, the completeness of the sphere of the spirit and the sphere of the mind $[4,9,10]$. The concept of the noosphere was first introduced into scientific use by the French philosophers T. de Chardin and Ed. Le Roy [11], but it was known to the ancient Greeks, and then successfully developed by Russian scientists, starting from the middle of the 19th century [20, 22-25]. P.I. Vernadsky defines noosphere as the direction and globality of evolution, the indestructibility and eternity of life [22]. But since evolution created the mind, it is he who should be assigned the main role in the joint history of human society and the biosphere, and their harmonious interaction will ensure the future of man- kind, which must take responsibility for the further evolution of the planet. Z.I. Kolycheva defines noosphere as harmonious relationships, interactions of the biosphere and human society, their co-evolutionary development. Noosphere as the highest level of nature's self-development in the field of practice reflects the humanistically moral and intellectually organized co-development of society and nature [9]. At the same time, the very process of forming a society capable of realizing the conditions of co-evolution is called noogenesis or noospherogenesis.

According to A.I. Subetto, noospheric educational paradigm corresponds to the idea of sustainable development and brings it to the new level of understanding the implications of destroying Nature by human beings [18]. Although UNESCO claims that the education of sustainable development is now a trend and builds up its competence model $[6,12]$, it is not enough. Since human civilization, including the educational sys- 


\section{Непрерывное образование в течение жизни...}

tem, is currently experiencing a deep crisis $[1,4]$, the issues of noogenesis are becoming especially relevant. It means that the development of society is primarily the spiritual development of each individual ready for productive interaction in accordance with Nature and common good to survive on Earth.

However, the situation of COVID19 pandemic showed how the modern world is losing its face-to-face communication becoming more computer-mediated, data-overwhelmed and online-dependent. Therefore, studying the challenges of distance learning, we face the necessity to identify new approaches that would help to use the advantages it provides to all the participants in the educational environment. So, sphere ideas and the synergistic approach are in the focus of our attention to formulate basic principles of noospheric pedagogy in relation to distance learning, to describe the formation of a noospheric personality and to develop the model of due competencies.

The theory of the noosphere is widely used in education, in particular, when considering some of the laws and rules concerning the formation of a noospheric personality $[2,4,5,9,10$, 14, 16, 18, 19]. Z.I. Kolycheva distinguishes the following points:

- noogenesis is possible with the development of egosystems (systems of formation and development of individual spiritual life);

- consciousness evolves into selfconsciousness, which is a mechanism of personality's awareness and development;

- to create a productive tandem of a human and nature, it is necessary, on the one hand, to increase the amount of memory (improving the information sphere), and on the other, to change the ethical principles of society and each human being in particular;

- cooperation, dialogue, partnership build relationships inside the society and between society and nature;

- group preservation is transforming to individual preservation, which requires maximum development of personality [9].

As N.G. Sviridova points out, that the transition from the biosphere (and the psychosphere) to the noosphere is a giant, planetary leap that will require creativity and moral qualities of all mankind and each individual; since the human consciousness is making a leap, its leading edge is all educational structures built on the basis of the new educational paradigm and pedagogical theory - pedagogy of evolutionary development (noosphere pedagogy) [19]. Based on empirical research, N.G. Sviridova comes to the conclusion about the development of noogenesis on the planet. Structural personal changes occur in thinking and in the "feeling" of mental processes, which changes the attitude towards the world and towards other people. Human consciousness becomes a part of a wide planetary system, and this, in turn, leads to their study in the framework of synergetics - a science that deals with the laws of universal evolutionary development [19]. From the point of view of synergetics, now we are observing a typical bifurcation process, when sufficiently stable qualities "explode" for further more efficient development. In times of crisis, both social and political instability, bifurcations are global $[4,7]$.

The concept of noospherism sets out the task of creating a productive tandem of man and nature. There are two possible ways to address this task: to increase the amount of memory (development of the information sphere) and to change the ethical attitudes of man and human society $[4,9]$. The optimal solution to this problem is possible precisely within the framework of distance learning with its high information density. According to the researchers in the field of distance technologies $[4,15,17]$, the text in the network becomes an autonomous object for a student to work with, like a multimedia constructor that has the tools to operate. As a result of putting his own efforts to achieve the educational goal, the student acquires positive emotions, which increase the motivation for learning. Thus, independent multimedia construction contributes to the formation of such qualities as a sense of responsibility, self-esteem and other aspects of the moral culture of the individual, which characterize the noospheric personality. Besides, multimedia elements create additional psychological structures that contribute to the perception and memorization of material [4]. It becomes possible to use the student's subconscious reactions, for example, summing up or giving out an assignment in each lecture of the course can be preceded by a sound or melody that tunes the student to a certain type of work. This type of work forms such a quality as sensitivity, which is significant for the noospheric personality.

In turn, changing the ethical attitudes requires competence-based approach that shifts the focus from the input to the outcome-oriented mode $[1,3,12]$. Here, it is important to foster 
people's engagement both globally - in the life of the whole society, and personally: in individually efficient ways of continuing learning improvement. From the point of view of biospheric ethics, humanity has no other way than the formation of a society capable of realizing the conditions of co-evolution of man and nature, when every man takes responsibility for the development of civilization. The human mind must join the evolutionary process, the man is forced to take responsibility for the further evolution of the planet, otherwise there will be no future.

So, let us summarise the main terms of the research. Noospheric pedagogy is interpreted as a process of creating optimal conditions for training and development of participants of the distance learning process, focused on the formation of a noospheric personality, which involves the formation of relevant educational goals and values. Distance learning is defined as a specially organized process of virtual-real interaction between a teacher and a student through a multimedia environment, aimed at the formation of a professional who has socially valuable moral qualities and considers learning as a permanent process of self-improvement and self-realization. Modern views of the noosphere regard it as a kind of ideal of the world order, based on humanitarian values: spirituality, integrity, freedom, creativity, which will allow a person to develop in harmony with the world around him. A person becomes a leading force: knowing nature, he learns to manage it without violating natural harmony, but creating new opportunities for its development, actively and carefully treats the environment. Thus, if we include these personality traits in the content of education and form them purposefully, we can consider the process of noogenesis, within which the formation of the noospheric personality takes place. Thus, the principle of cultural and natural conformity underlies the formation of the competencies of a noospheric personality, showing the way to achieve harmony and productive interaction of all the participants of the distance learning process with the outside world.

\section{Materials and Methods}

Taking generally noospheric and synergetic approaches for analyzing the interaction of participants in the educational process with distance education, we focus on those positions that are significant for the problem we have identified:

1. The pedagogy of noospheric development is an alternative to the degradation of humanity from a narrow, self-centered consumptionoriented consciousness. This means that the human mind has reached such a degree of development that it can either contribute to evolution or lead to the self-destruction of mankind.

2. The energy-information exchange that exists between a person and the Universe and which is realized by a person depends on such qualities as sensitivity, conscientiousness (imbalance from the standpoint of synergetics), openness to the world and people, spirituality (dissipativity from the point of view of synergetics), mercy (ability to cooperative movement from the point of view of synergetics), etc. Therefore, pedagogy must form a personality that moves from the goals of professional necessity to the goals of professional and personal dignity.

3. Only self-developing systems are included in noogenesis, therefore, the pedagogical process is a self-developing, open, flexible, and dynamic system. This means that the educational process creates the atmosphere of dialogue, creative search, trust, imagination, intuition, etc. Fourth, in the noosphere pedagogy the role of the teacher as the creator and "harmonizer", as the bearer of the new noosphere ethics, is rising.

These points are crucial for the educational organization of distance learning that is conceptually based on the idea of efficient interaction among the participants as an essential element of educational programs. This interaction can have the following challenges:

1. Students work most of the time on their own and cannot always ask their teacher a question instantly, so the programs should maximize interactive communication.

2. The learning process is not personalized in terms of the fact that students do not see the teacher, so the programs should have thoroughly planned and developed trajectories.

3 . The information flow during distance learning is complex in its dynamics, since it is based on various technologies that require certain gadgets and competences, so the programs should guide the students throughout the courses $[15,17,21]$.

All in all, to address the three challenges a distance learning course should be well planned, interactive, and organized to bridge the gap of student-teacher's face-to-face absence and to employ the advantages that modern IT sphere can offer.

The computerization and informatization of education are significantly changing the essence 


\section{Непрерывное образование в течение жизни...}

of educational technologies, and it cannot but lead to a change in the result of this process, namely to the formation of a new type of personality, characterized by a different logic of value orientations and that fits into the humanitarian educational paradigm. The center of such a paradigm is not a student who assimilates ready-made knowledge, but a person who is learning the essence and searching for the truth. At the same time, the relations between the teacher and students are built on the principles of dialogue, cooperation, polylogue, co-creation, mutual responsibility for the free choice of one's position. Here in such an interaction the participants in the pedagogical process exchange not only knowledge, but also individual unique ideas, understanding of the problems and creativity.

The energy-information exchange that takes place in any educational environment suggests that the purpose of education is fundamentally changing. And if the general pedagogical goal of distance learning is the formation of a noospheric personality, then the students themselves formulate this goal differently. Their new goal is professional and personal dignity as parts of individual culture. As V.I. Vernadsky, the author of the doctrine of the noosphere, claimed the spirit of scientific search is identical and inextricably linked with a sense of human dignity [23]. The broadest meaning of the concept of dignity is respect for others and respect for oneself; in professional sense, it is about respecting both one's own profession, and any other, aimed at human benefit. One more quality that develops when setting this goal is sensitivity. This is the ability of a person to respond to external and internal excitations, excitements, experiences, the ability to respond to the slightest changes in the mental state of another person with very little contact with him. This is followed by such a quality as conscientiousness, which includes a system of moral values that allow judging other people. The concept of conscience includes many other moral traits that become a moral law. The formation of the noospheric personality is correlated with the acquisition and appropriation of social moral laws by the individual. This group of qualities includes mercy as a feeling of compassion, forgiveness, pity. The combination of these qualities is realized in openness and spirituality. These qualities form the peculiar culture of the noospheric personality, as well as the culture of his or her interaction with other people and with the world. They form a sense of res- ponsibility for the person him/herself and for others.

Noospheric pedagogy pays attention to selfdirected development of the individual, the ability to provide alternative trajectories and, as a result, avoidance of rigid planning and giving students the opportunity to choose their own path $[4,10$, 16]. Thus, the culture of cognitive and creative activity is being improved. Distance education opens up broad possibilities specifically for selfand alternative development:

1. The multimedia course can be used multiple times and multifunctionally.

2. A part of a course or lecture can constitute an independent fragment of the lesson, and if for some students it is repeated in order to master the material, then for others one-time presentation with subsequent creative reproduction is sufficient. The multimedia course is mastered by the student individually.

3. There are additional possibilities for managing students' cognitive activity by providing them an extended model of a lecture course that requires constructive associations, reflections, and argumentation.

4. The student can choose the course that seems the most relevant, participate in teleconferences, television discussions, which will lead him to personal, intellectual and moral growth.

5 . Working on the Internet, which is an integral component of distance education, the student creates his own educational space, collecting scientific resources. This factor is, in our opinion, significant, since one of the characteristic features of trait genesis is the transition from group preservation to preservation of the individual. If, in the process of working on the preparation of scientific and educational resources for the discipline, a student has made his own efforts, the educational space he creates will be much more important for him/her.

The feature of pedagogical interaction system in distance learning mode is that the pedagogical environment is radically changing, turning into the multimedia educational space [3]. The spatio-temporal remoteness of the teacher and the student and their indirect-direct, virtualreal interaction weaken the traditional "strong bonds" between the teacher and the student. As a result, there is a serious risk of breaking these bonds. To prevent it, pedagogy is learning how to manage the multimedia environment with genuine teacher-student interaction, in order to bridge the gap. 


\section{Results and discussion}

As a result of thorough analysis of all the theoretical sources and our teaching experience, we are presenting two pedagogical models: model of distance learning participants' interaction system in the aspect of noospheric pedagogy and the competence model of noospheric personality. According to the classification of pedagogical models by E.A. Lodatko, our first model represents function and structure and our second one shows content and structure [13]. These two different types of models make it possible to illustrate competence formation of noospheric personality from all three angles: content, structure and function. Thus, we can not only observe the pedagogical process, but use the models in real distance learning course development.

To model the function and structure of distance learning interaction, we need to define the elements of distance noospheric pedagogical system. According to the data analysis, it constitutes of the following parts:

- setting the goal of distance education: the formation of a noospheric personality;

- changing the mentality of students enrolled in the distance learning regime;

- transforming the mentality of teachers in terms of noospheric ethics,
- interacting of tutors with program developers in specific disciplines, web designers and other technical specialists who ensure the smooth functioning of the distance learning system;

- providing computers and other multimedia teaching aids;

- creating computer programs as an embodiment of human culture in various fields of knowledge;

- identifying and developing the components of personality's spiritual culture both for the teacher and student: ideals, beliefs, worldview;

- presenting basic human values and forming new ones;

- developing intellectual and creative abilities of the individual;

- introducing didactic methods for presenting computer programs, etc.

To show the structure of this system, we offer its diagram (Fig. 1) and provide the explanation what is its fundamental difference from other existing pedagogical models, regardless of whether they are presented in a graphic or verbal form.

Firstly, to replace the traditional vertical model of the teacher's influence on the student, we put forward the idea of a horizontal model of interaction between the student and the teacher, which indicates the creation and building of equal

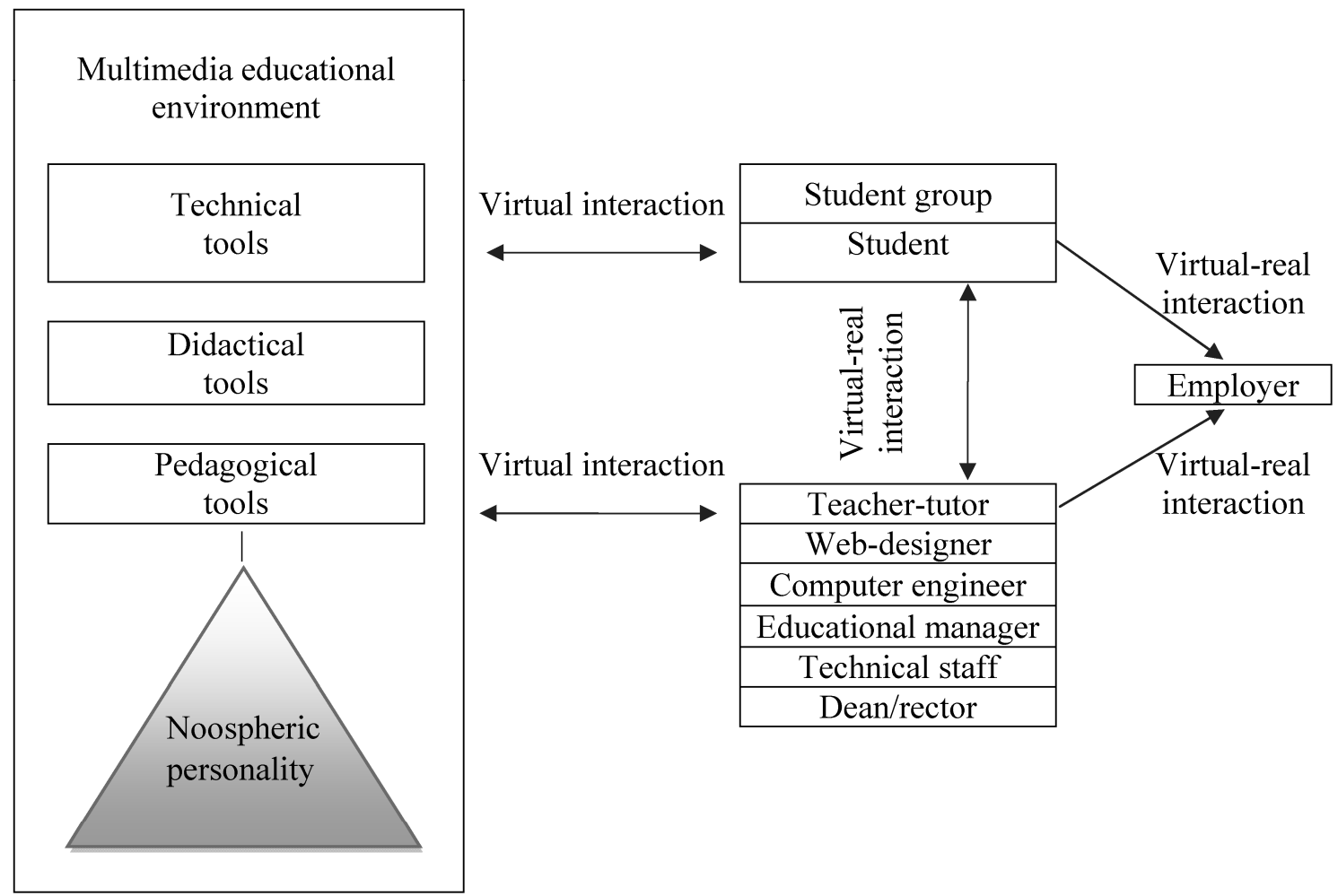

Fig. 1. Model of distance learning participants' interaction system in the aspect of noospheric pedagogy 


\section{Непрерывное образование в течение жизни...}

partnership relations between the student and the teacher-tutor.

Secondly, the subject-object relationship, where the teacher acted as a subject, and the student as an object to whom a certain amount of knowledge and information must be conveyed, gave way to subject-subject equal relationships, where the student himself acquires knowledge, relying on to cyberspace, working in an asynchronous mode of time and place. In addition, in this model, the student takes a higher position in comparison with the teacher, so it is no coincidence that the teacher acts as a tutor. Thus, his teaching functions undergo significant changes, even if the teacher performs the tasks of two tutors: the coordinator of the educational process and the developer of the curriculum.

Thirdly, a virtual-real interaction is established between a student and a teacher-tutor as participants of the distance educational process.

Fourth, the position of the next component of the educational process has been strengthened, which in the traditional education system can be conditionally called educational material. In the system of distance education, this component is called a multimedia educational environment or cyberspace. It is its functioning that underlies the new system of interaction. Both the teacher and the student build a virtual interaction with cyberspace. Its components can be roughly divided into three groups: 1) technical; 2) didactic; 3) pedagogical. The technical group includes the operation of computer learning technologies, computer operation, Internet, logistics, etc. The didactic group includes didactic ways of presenting computer programs, the formation of student's individual didactic trajectory, etc. The pedagogical group solves the problems of the formation of a noospheric personality, the formation of personality's spirituality, including moral culture, cognitive culture, aesthetic culture, creative culture, and the formation of a civic consciousness. The same group includes presenting universal human values, the formation of a worldview, ideals, beliefs, the development of intellectual and creative abilities, and a change in mentality. At the same time, the emphasis is placed not only on the development of students and teachers' certain spiritual qualities, but on their harmonization, which is the main function of a teacher-tutor.

Fifth, the system also includes other participants: student group, web designers, education managers, technicians, computer engineers, and employers. In all cases, virtual-real interaction is established. Moreover, the circle of stakeholders can be expanded, but the essence of the interaction will not change.

Based on this view of all participants in pedagogical interaction, it becomes clear that the teacher from the central figure of pedagogical influence turns into one of the components of this chain, therefore, a special organization of his activities is necessary, which would return him, at least partially, to his former role. We believe that changes occur in teacher's mentality, because the teacher in noospheric pedagogy is assigned the role of a "harmonizer" of society, a teachercreator, a carrier of a new ethics, a new worldview.

To make a competence model of noospheric personality we selected five special competencies that reveal the content of the principle of nature and cultural conformity: competence of civic consciousness, competence of values and sense of purpose in the World, competence of selfimprovement, self-awareness, self-development, competencies of social interaction, competence of information technology (Fig. 2). To form these competencies, the person needs the following qualities: spirituality, integrity, freedom, and creativity. As a result, the students develop their personal culture that contains four components, each two of which form one after another in turn: moral and aesthetic and cognitive and creative.

The competence of civic consciousness is highlighted in the model, because we see it as the key in the context of noospheric distance education. First, it is absolutely social, as it is developed and formed in society. Secondly, it ensures the normal life of a person in society. Thirdly, it characterizes the interaction of a person with society, with other people. It belongs to the competencies of social life and human interaction in society and has a personal positive ideological basis. Therefore, we point out that the competence of civic consciousness, which includes a certain range of personal qualities, acquires the features of professional competence in the process of distance learning. Relying on the competence of civic consciousness as a basic, key one in the process of forming a noospheric personality, we are confident about tomorrow, despite the systemic crisis that modern mankind is experiencing. The evolutionary process is capable of realizing noogenesis and ending with the noosphere. In the course of the evolution 


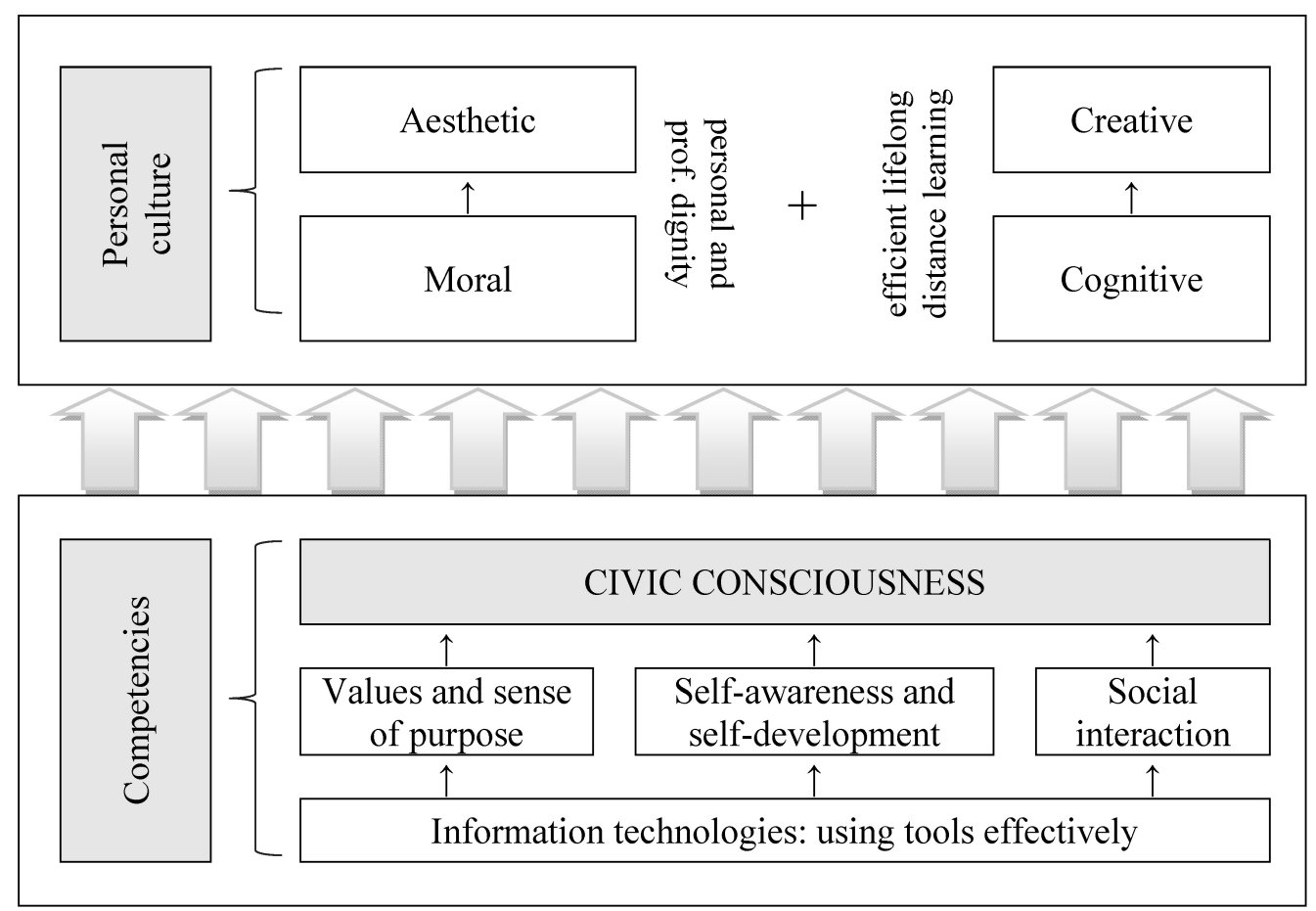

Fig. 2. Noospheric personality: competence model

of biological and social systems, there is a gradual involvement of society in the biosphere, aimed at forming a personality. If this did not happen, the person would be in danger of personal destruction.

\section{Conclusion}

It should be noted that the ideas of the noospheric school have not been previously studied within the framework of distance education. The competence components of the noospheric personality of the teacher and student, whose activities are carried out in a multimedia environment that integrates modern information technologies, are new to investigate. In the conditions of cyberspace, the roles and functions of all participants of the distance learning process, primarily the teacher and the student, are changing radically. In this study, we systemized the concept of their interaction, to make it possible to harmonize both teacher and student's intellectual and spiritual development, which allows to reach a new ultrahigh level of interaction essential in noosphere.

\section{References}

1. Adomßent M., Hoffmann T. The Concept of Competencies in the Context of Education for Sustainable Development (ESD), 2013. Available at: http://esd-expert.net/assets/130314-ConceptPaper-ESD-Competencies.pdf 01.07.2020).
2. Fedorova M.A. Pedagogicheskaya sinergetika kak osnova modelirovaniya $i$ realizatsii deyatel'nosti prepodavatelya vysshey shkoly. Dis. kand. ped. nauk [Pedagogical Synergy as a Basis of Modeling Realization of a Lecturer at the University. Diss. Cand. (Pedagogy)]. Stavropol', 2004. $164 \mathrm{p}$.

3. Geykhman L.K. Interaktivnoe obuchenie obshcheniyu (obshchepedagogicheskiy podkhod). Avtoref. kand. diss. [Interactive Teaching of Communication (Pedagogic Approach). Abstract of Cand. Diss.]. Ekaterinburg, 2003. 40 p.

4. Geykhman L.K., Kushnina L.V., Kushnin A.V. Sinergeticheskaya pedagogika [Synergetic Pedagogy]. Perm', 2011. 176 p.

5. Goldshmidt E.S., Gritskevich T.I., Mesheryakova S.M., Cherepanov A.Y. Concept of Noospheric Education: Innovative Methods for Developing Personal Cognitive Strategies. The European Proceedings of Social and Behavioural Sciences. RPTSS 2017 - International Conference on Research Paradigms Transformation in Social Sciences. Tomsk Polytechnic University, Russia, 2017, pp. 383-394. DOI: 10.15405/ epsbs.2018.02.45

6. Goodland R., Daly H., El Serafy S. Environmental Sustainable Economic. Development. Building on Brundtland. Washington DC, World Bank Publ., 1991.

7. Haken H., Haken-Krell M. Tayny vos- 


\section{Непрерывное образование в течение жизни...}

priyatiya. Sinergetika kak klyuch $k$ mozgu [Ergolgsgeheimnisse der Wahrnehmung. Synergetik als Schlüssel zum Gehirn]. German translation: A.R. Logunova. Moscow, 2002. 272 p.

8. Jansen M., Uexkull E. Trade and Employment in the Global Crisis. Geneva: International Labour Office. Available at: www.ilo.org/ wcmsp5/groups/public/---dgreports/---dcomm/--publ/documents/publication/ wcms_141911.pdf (accessed 01.07.2020).

9. Kolycheva Z.I. [Noogenesis. Educational Goals and Values]. Tumen State University Bulletin, 2003, no. 4, pp. 162-169. (in Russ.)

10. Kushnin A.V. [Noospheric Personality Formation as an Axiological Dominant Idea of Distance Learning]. Teoriya i praktika perevoda $i$ professionalnoy podgotovki perevodchikov: proceedings of international scientific-practical conference (Perm, Fabruary 16-17 2005) [Theory and Practice of Translation and Professional Training of Translators: Mater. Int. Scientificpractical Conf. (Perm February 16-17, 2005)]. Perm, 2005, pp. 318-322. (in Russ.)

11. Kushnin A.V., Kushnina L.V. K osnovaniyam noosfernoy pedagogiki: spetskurs dlya distantsionnogo obrazovaniya [To the Basics of Noospheric Pedagogy: Special Course for Distance Learning]. Perm', 2006. 100 p.

12. Le Roy Ed. Les Origines Humaines de L'evolution de L'intelligence, 1931.

13. Leicht A., Heiss J., Byun W.J. Issues and Trends in Education for Sustainable Development. Education on the Move, UNESCO Publishing Publ., 2018. 276 p.

14. Lodatko E.A. [Typology of Pedagogical Models]. Science Vector of Togliatti State University. Ser. Pedagogy, Psychology, 2014, no. 1 (16), pp. 126-128. (in Russ.)

15. Maslova N.V., Antonenko N.V., Alekseeva O.A. [Nature-aligned Education Technologies as the Basis of Forming an Individual Noospheric Consciousness]. Open Education, 2017, vol. 21, no. 5, pp. 14-21. (in Russ.) DOI: 10.21686/1818-4243-2017-5-14-21

16. Polat E.S. Teoriya i praktika distantsionnogo obucheniya [Theory and Practice of
Distance Learning]. Moscow, Academia Publishing Publ., 2004. 416 p. (in Russ.)

17. Sikorskaya G. Noospheric Pedagogy: The Expansion of the Humanitarian Space of Vocational and Pedagogical Education. International Journal of Environmental and Science Education, 2016, no.11, pp. 6963-6975.

18. Subetto A.I. (Ed.) Noosfernoe obrazovanie $v$ evraziyskom prostranstve: kollektivnaya nauchnaya monografiya. Tom pyatyy. Noosfernoevraziyskaya paradigma fundamentalizatsii nepreryvnogo obrazovaniya [Noospheric Education in the Eurasian Environment: Collaborative Monograph. Vol. 5. Noospheric Paradigm of Continuing Education Fundamentals]. St. Petersburg, Asterion Publishing, 2015. 466 p.

19. Stavtseva I.V., Kolegova I.A. Innovative Technology in Blended Learning: General English Course Design and Its Implementation for University Students. Bulletin of the South Ural St. Univ. Ser. Education. Educational Sciences, 2020, vol. 12, no. 2, pp. 51-61. DOI: $10.14529 /$ ped200205

20. Sviridova N.G. [Person's Noospheric Development in the Methodology of Developing Education]. Developmental Training. Methodological and Technological, 1998, iss. 2, pp. 37-48. (in Russ.)

21. Trubetskova I.L. From Biosphere to Noosphere: Vladimir Vernadsky's Theoretical System as a Conceptual Framework for Universal Sustainability Education. Available at: https:// scholars.unh.edu/dissertation/612 (accessed 20.07.2020).

22. Ursul A.D. [Informatization of Society and Transition to Sustainable Development of Civilization]. ROIVT Bulletin, 1993, no. 1-3, pp. 35-45 (in Russ.)

23. Vernadsky V.I. Biosfera $i$ noosfera [A Few Words about Noosphere]. Moscow, Pedagogika-Press Publ., 1993. (in Russ.)

24. Vernadsky V.I. Neskol'ko slov o noosfere [Bioshpere and Noosphere]. Moscow, Nauka Publ., 1989. $261 \mathrm{p}$.

25. Yakovlev V.P. V.I. Vernadskiy [V.I. Vernadsky]. Moscow, MarT Publ., 2005. 80 p.

Received 12 August 2020 


\title{
КОМПЕТЕНЦИИ НООСФЕРНОЙ ЛИЧНОСТИ В УСЛОВИЯХ ДИСТАНЦИОННОГО ОБРАЗОВАНИЯ
}

\author{
Л.К. Гейхман ${ }^{1}$, И.В. Ставцева ${ }^{2}$ \\ ${ }^{1}$ Пермский национальный исследовательский политехнический университет, \\ г. Пермь, Россия, \\ ${ }^{2} Ю$ жн-Уральский государственный университет, г. Челябинск, Россия
}

\begin{abstract}
Человеческая цивилизация проходит период глубокого кризиса, что выводит на первый план вопросы ноогенеза, означающего приоритет духовного развития отдельного индивида, который готов к продуктивному взаимодействию в целях сохранения планеты от разрушающего воздействия человека. Однако пандемия COVID19 сегодня явно демонстрирует, насколько современный мир теряет реальное взаимодействие, переходя к опосредованному технологиями, зависимому от онлайн обмену избыточными данными, что обрисовывает рамки назревшего противоречия между необходимостью развития компетенций ноосферной личности и недостатком человеческого взаимодействия. Следовательно, в современных условиях формированию ноосферной личности необходимо уделять большее внимание, и эта задача может быть решена при помощи педагогической науки. Данная статья посвящена определению понятия ноосферной личности и моделированию процесса формирования необходимых компетенций в условиях дистанционного образования. Цель исследования - смоделировать процесс формирования компетенций в дистанционной ноосферной среде. Используемые методы включают анализ литературы и моделирование педагогического процесса. Результаты представлены в двух взаимосвязанных педагогических моделях: модель взаимодействия субъектов дистанционного образовательного процесса с точки зрения ноосферной педагогики и компетентностная модель ноосферной личности. При этом модель взаимодействия дает представление о структуре коммуникации при дистанционном образовании, в то время как компетентностная модель раскрывает содержание процесса формирования ноосферной личности, отражая переход от компетентности к культуре личности и демонстрируя значимость компетенции гражданственности, которая является основным двигателем изменений. Исследование показывает новый эффективный подход к пониманию образовательного кризиса и может быть использовано в качестве основополагающего для разработки программ дистанционного образования и обучающих курсов.

Ключевые слова: ноосферная личность, ноосферная педагогика, дистанционное обучение, синергетическая педагогика, формирование компетеничй, коэволючиионное взаимодействие.
\end{abstract}

\section{Лumepamypa}

1. Adomßent, M. The Concept of Competencies in the Context of Education for Sustainable Development (ESD) / M. Adomßent, T. Hoffmann. - http://esd-expert.net/assets/130314-Concept-Paper-ESDCompetencies.pdf (дата обращения: 01.07.2020).

2. Федорова, М.А. Педагогическая синергетика как основа моделирования и реализации деятельности преподавателя высшей школь: дис. ... канд. пед. наук / М.А. Федорова. - Ставрополь, 2004. $-164 \mathrm{c}$.

3. Гейхман, Л.К. Интерактивное обучение общению (общепедагогический подход): автореф. дис. ... д-ра пед. наук / Л.К. Гейхман. - Екатеринбург, 2003. - 40 с.

4. Гейхман, Л.К. Синергетическая педагогика / Л.К. Гейхман, Л.В. Кушнина, А.В. Кушнин. Пермь: Изд-во Перм. гос. техн. ун-та, 2011. - 176 с. 


\section{Непрерывное образование в течение жизни...}

5. Goldshmidt, E.S. Convcept of noospheric education: innovative methods for developing personal cognitive strategies / E.S. Goldshmidt, T.I. Gritskevich, S.M. Mesheryakova, A.Y. Cherepanov // The European proceedings of social and behavioural sciences. RPTSS 2017 - International conference on research paradigms transformation in social sciences. - Tomsk Polytechnic University, 2017. P. 383-394.

6. Goodland, R. Environmental Sustainable Economic. Development. Building on Brundtland / R. Goodland, H. Daly, S. El Serafy. - Washington DC: World Bank, 1991.

7. Хакен, Г. Тайны восприятия. Синергетика как ключ к мозгу / Г. Хакен., М. Хакен-Крелль; пер. с нем. А.Р. Логунова. - М., 2002. - 272 с.

8. Jansen, M. Trade and Employment in the Global Crisis. Geneva: International Labour Office / M. Jansen, E. Uexkull. - http: www.ilo.org/wcmsp5/groups/public/---dgreports/---dcomm/---publ/ documents/publication/wcms_141911.pdf (дата обращения: 01.07.2020).

9. Колычев, 3.И. Ноогенез. Цели и ценности образования / 3.И. Колычев // Вестник Тюмен. гос. ун-та. - 2003. - № 4. - C. 162-169.

10. Кушнин, А.В. Формирование ноосферной личности как аксиологическая доминанта дистанционного образования / А.В. Кушнин // Теория и практика перевода и профессиональной подготовки переводчиков: материалы междунар. науч.-практ. конф. (Пермь 16-17 февр. 2005). Пермь, 2005. - С. 318-322.

11. Кушнин, А.В. К основаниям ноосферной педагогики: спецкурс для дистаниионного образования / А.В. Кушнин, Л.В. Кушнина. - Пермь: Изд-во Перм. гос. техн. ун-та, 2006. - 100 с.

12. Le Roy Ed. Les origines humaines de l'evolution de l'intelligence / Roy Ed Le. - 1931.

13. Leicht, A. Issues and Trends in Education for Sustainable Development / A. Leicht, J. Heiss, W.J. Byun. - Education on the move, UNESCO Publishing, 2018. - 276 p.

14. Лодатко, Е.А. Типология педагогических моделей / Е.А. Лодатко // Вектор науки Тольяттин. гос. ун-та. Серия «Педагогика, психология». - 2014. - № 1 (16) - С. 126-128.

15. Maslova, N.V. Nature-aligned Education Technologies as the Basis of Forming an Individual Noospheric Consciousness / N.V. Maslova, N.V. Antonenko, O.A. Alekseeva // Open Education. - 2017. Vol. 21, no. 5. - P. 14-21.

16. Теория и практика дистанщионного обучения / под ред. Е.С. Полат. - М.: Академия, 2004. $-416 c$.

17. Sikorskaya, G. Noospheric Pedagogy: The Expansion of the Humanitarian Space of Vocational and Pedagogical Education / G. Sikorskaya // International journal of environmental and science education. - 2016. - No. 11. - P. 6963-6975.

18. Ноосферное образование в евразийском пространстве: коллектив. науч. моногр. Том пятый. Ноосферно-евразийская парадигма фундаментализачии непрерывного образования / под науч. ред. А.И. Субетто. - СПб.: Астерион, 2015. - 466 с.

19. Stavtseva, I.V. Innovative Technology in Blended Learning: General English Course Design and Its Implementation for University Students / I.V. Stavtseva, I.A. Kolegova // Вестник ЮУрГУ. Серия «Образование. Педагогические науки». - 2020. - Т. 12, № 2.- С. 51-61.

20. Свиридова, Н.Г. Ноосферное развитие человека в методологии развивающего обучения / Н.Г. Свиридова // Развивающее обучение. Вопросы методологии и технологии. - 1998. - Bып. 2. C. 37-48.

21. Trubetskova, I.L. From biosphere to noosphere: Vladimir Vernadsky's theoretical system as a conceptual framework for universal sustainability education / I.L. Trubetskova. - https://scholars. unh.edu/dissertation/612 (дата обращения: 20.07.2020).

22. Урсул, А.Д. Информатизация общества и переход к устойчивому развитию цивилизации । А.Д. Урсул // Вестник РОИВТ. - 1993. - № 1-3. - С. 35-45.

23. Вернадский, В.И. Биосфера и ноосфера / В.И. Вернадский. - М.: Наука, 1989. - 261 с.

24. Вернадский, В.И. Несколько слов о ноосфере / В.И. Вернадский // Антология философской мысли. Русский космизм. - М.: Педагогика-Пресс, 1993.

25. Яковлев, В.П. В.И. Вернадский / В.П. Яковлев. - М.: МарТ, 2005. - 80 с. 
Гейхман Любовь Кимовна, доктор педагогических наук, профессор, профессор кафедры иностранных языков, лингвистики и перевода, Пермский национальный исследовательский политехнический университет, г. Пермь, glk@pstu.ru.

Ставцева Ирина Вячеславовна, кандидат педагогических наук, доцент кафедры лингвистики и перевода Института лингвистики и международных коммуникаций, Южно-Уральский государственный университет, г. Челябинск, stavtsevaiv@susu.ru.

Поступила в редакцию 12 августа 2020 2.

\section{ОБРАЗЕЦ ЦИТИРОВАНИЯ}

Geykhman, L.K. Noospheric Personality: Competencies in Distance Learning Environment / L.K. Geykhman, I.V. Stavtseva // Вестник ЮУрГУ. Серия «Образование. Педагогические науки». - 2020. - Т. 12, № 4. - С. 27-37. DOI: $10.14529 /$ ped200403

\section{FOR CITATION}

Geykhman L.K., Stavtseva I.V. Noospheric Personality: Competencies in Distance Learning Environment. Bulletin of the South Ural State University. Ser. Education. Educational Sciences. 2020, vol. 12, no. 4, pp. 27-37. DOI: $10.14529 /$ ped200403 